\title{
Studies on Characteristics, Applications and Strength Improvement of Marine Clay: A Review
}

\author{
R. Saisubramanian, V. Murugaiyan, T. Sundararajan \\ Department of Civil Engineering, Pondicherry Engineering College, Puducherry, India \\ Email: sai_radhika1@yahoo.co.in
}

How to cite this paper: Saisubramanian, R., Murugaiyan, V., \& Sundararajan, T. (2019). Studies on Characteristics, Applications and Strength Improvement of Marine Clay: A Review. Journal of Geoscience and Environment Protection, 7, 93-106. https://doi.org/10.4236/gep.2019.71008

Received: December 9, 2018

Accepted: January 20, 2019

Published: January 23, 2019

Copyright () 2019 by author(s) and Scientific Research Publishing Inc. This work is licensed under the Creative Commons Attribution International License (CC BY 4.0).

http://creativecommons.org/licenses/by/4.0/

\begin{abstract}
Strength assessment and improvement of strength parameters are essential to design the foundation in clay and marine clay. Several studies have been made in this aspect. Marine clay is also a potential material for use as liner material to contain landfill leach ate. The applications include use of marine clay for transforming waste into light weight aggregates and thus create better environment. The physical parameters such as Atterberg limits, California Bearing Ratio (CBR) value, dry density, specific gravity, free swell, chemical properties such as $\mathrm{p}^{\mathrm{H}}$ value, cation exchange capacity, organic matter content, calcium carbonate, and mineralogical composition using X-ray diffraction analysis are studied. The consolidation characteristics, determination of strength improvement strategies using admixtures at different proportions are frequently adopted. Commonly used admixtures are lime, limes mixed with cement, coir, shredded plastics. The consolidation studies are very vital and play an important role.
\end{abstract}

\section{Keywords}

Marine clay, Consolidation Characteristics, Admixtures, Aggregates, Land Fill

\section{Introduction}

Marine clay is often considered as problematic soil in view of its low strength rendering it as unsuitable for any engineering activity in its naturally occurring condition. Geotechnical engineers have been working constantly to improve the characteristics such as: strength, consolidation characteristics, behavior when admixed with strength imparting additives like lime, cement and a host of other 
materials to meet the specific requirements primarily based on the development enviaged. This has triggered several methods being developed around the world which are essentially demand driven. Consequently, several studies on marine clay are carried out in different parts of the world for meeting site specific strength requirements. Studies are also carried out to determine the use of marine clay for other purposes, such as a liner material for containing leach ate in landfill. Study of the formation of marine clay and its characteristics has been extensively done in several parts of the world for assessing its strength, consolidation, strength improvement methods and strength assessment on time scale. Marine clay also possesses very useful applications such as landfill material, as a medium for effectively retain heavy metals which are encountered in leachate from waste disposal sites. The focus area of study is on suitability of marine clay for other purposes such as heavy metal retention, used as an admixture for production of aggregates thereby mitigating pollution from waste materials such as industrial slag. This has greatly encouraged soil specialists, geologists and geotechnical engineers to take a relook at the means of making best use of marine clay for environment protection.

The soils on the sea bed are pelagic or terrigenic that is either naturally formed or brought from rivers joining the sea. The transported soil received in the sea bed is also subjected to changes due to the sea environment. Hence the characteristics of soil are varied along coast line. The process of formation of marine clay along the eastern Arabian Sea has its source of deposition from Sindhu River and the eolian deposits from Thar and Arabian deserts (Avinash et al., 2015).

The study of marine clay for its characteristics, strength, improvement methods for development of strength, applications as a material for land fill and heavy metal retention capabilities have been evincing interest from all over the world. The need to address these parameters arises from the fact that seaports provide logistics support. The development of ports and the infrastructure requirements triggered the extensive investigation on the strength aspect of marine clay. Several studies have been carried out on the strength and strength improvement methods of marine clay predominantly along coast line and near shore areas (Mersi, 2012; Suskun Horpibulsuk et al., 2012; Indrarathna, B. et al., 2013; Chayakrit Phetchuay et al., 2016; Tao Zhanh et al., 2018; Xiao et al., 2017; Takashi Tsuchida \& Tang, 2015). The consolidation characteristics are investigated along the marine clay deposits along Northern Arabian Gulf with the aim of proposing a coefficient of consolidation with the stress level of marine clay (Elkateb, 2017). Deep mixing of cement for improvement of strength of marine clay is a method commonly adopted (Shen et al., 2008; Arasan et al., 2015). Further it is seen that the study of the yielding behavior of cement admixed marine clay in terms of its strength suggests that despite several investigations remain elusive in deriving simple relationship for mix ratio (Consoli \& Prietto, 2006; Xiao et al., 2014). The response of marine clay subjected to cyclic loading in terms of stress strain behavior (Anil Kumar et al., 2010) and the soil structure 
effect is studied in depth for assessment of the strain development and pore water pressure (Leng et al., 2018). The findings of many studies are considered in this review to serve as a tool for choosing a more proven method for addressing the real life situations in a more effective manner.

\section{Studies on the properties of marine clay and its applications}

The hydraulic conductivity determines the suitability of marine clay for use as liner material. Marine clay also possesses capacity to retain heavy metals. The basic physical and chemical properties and mineralogical composition of marine clay is carried out to determine the consolidation characteristics, strength and methods to improve its strength by adopting various techniques such as use of admixtures like lime and cement. Dredging of water channels and other maintenance works in ports generate huge quantity of soil for disposal. When the strength of filled up area is improved it is useful for carrying out development works. The strength improvement of marine clay is achieved by addition of lime, cement, fly ash or both in appropriate proportion.

Marine clay mixed with cement up to $10 \%$ is usually adopted for use as land fill material. Improvement using lesser quantity of $7 \%$ was investigated for assessing the strength gain. It was reported that the mechanical behavior of lesser cement mixed marine clay is not very different from that of mix having higher cement content as far as the compressive strength but varies with deformation modulus (Usama Khalid et al., 2018). Marine clay mixed with incinerator bottom ash as admixture was investigated for its strength improvement by adopting vacuum preloading in laboratory for assessing the strength and suitability for use of marine clay-incinerator bottom ash. The sample used is collected from the marine clay excavated for the formation of marina expressway in Singapore, as a land fill material for reclamation of land meeting the strength requirement. It was reported that the simulation study conducted indicated a strength gain of around 20kpa with the addition of 30\% admixture (Lin \& Wu, 2018). The effectiveness of a combination of chemical and physical methods for treatment of marine clay slurries was studied for using as an effective landfill material possessing adequate strength for heavy duty activities. The conventional method such as vacuum preloading has limitation on achievable bearing capacity. When the initial moisture content is high, chemical physical method is very useful. Use of geo bags investigated under simulated conditions is reported to significantly increase the rate of consolidation (Wu et al., 2015).

Application of marine clay as a liner material is one of the most useful and environment friendly means of utilizing the marine clay beneficially, requiring assessment of its physical properties, presence of chemical substances and more importantly mineral composition. The case studies reported as carried out in various places provide a better picture of the variations and complexities encountered and the methods adopted for converting in for useful applications. The marine clay deposits along the coast of Malaysia were studied for its suitability for use as liner material for containing leachate from landfill. When the ratio between plastic limit and liquid limit of the sample studied is in the range of 
0.4 - 0.6 it typically represents marine clay. The basic requirement is low permeability. The hydraulic conductivity is required to be less than or equal to $1 \times$ $10^{-9} \mathrm{~m} / \mathrm{sec}$. The particle size distribution, Atterberg limit, permeability and compaction tests were carried out for determining the characteristics of clay samples. X-ray diffraction tests were also conducted for determination of mineralogical composition. It was reported the clay minerals such as montmorollinite, Kaolinite and illite are present in the samples collected along the coastal area of Kuala Muda, kedah, Malaysia. The marine clay tested also possesses very low permeability in the range of $1.1-2.44 \times 10^{-9} \mathrm{~m} / \mathrm{sec}$. The hydraulic conductivity is reported to further reduce during consolidation thereby making it as a suitable liner material (Rahman et al., 2013).

Besides being used as a landfill material when admixed with cement or lime, the study on density is carried out for use as a sealant in nuclear waste storage facilities. Study of industrial slag from copper slag recycling process mixed with marine clay was conducted for use in land fill as a means of waste disposal in a productive manner. Use of a mixture of bentonite clay and bentonite pellets mixed in equal ratio is tested under laboratory conditions and found to achieve desired dry density for use as a heterogeneous compacted soil sealant in underground nuclear waste repositories (Gens et al., 2011).

Attempts have been made across the world for using a combination of Marine clay and waste generated such as marble tile rejections, industrial slag and bio mass as an effective means of converting waste in to useful resources. Waste handling is an important area where marine clay has useful application. The effect of mixing granite tile with the marine clay in improving the index properties was studied in laboratory using the marine clay sample from one of the dumping sites in Johor, Malaysia along with the discarded granite tiles which is mixed in dust form. It was reported that the granite tile addition was effective in increasing the plasticity. The other advantage is the use of granite material that is discarded and dumped as waste (Zainuddin et al., 2019).

The strength assessment of soft clay in Bangkok, Thailand using an admixture of fly ash and biomass ash blended with cement has been studied from the soil collected at depth of about $3 \mathrm{~m}$. It was reported that fly ash and bio mass ash proved as waste dispersing materials when cement is used for stabilisation. (Horpibuluk et al., 2011). Marine clay is also used to handle industrial sludge and convert it in to useful products such as light weight aggregate. Marine clay when mixed with industrial sludge obtained from copper slag recycling process is reported to produce light weight aggregates. The industrial sludge from copper slag recycling process was mixed with marine clay and is subjected to thermal processing fired at a temperature of $1200^{\circ} \mathrm{C}$ for producing light weight aggregate (Show et al., 2005).

Heavy metal retention capability of marine clay often used to contain pollution from land fill lecheate and in waste handling facilities. The marine clay sample obtained from Cochin greater area, India, is tested for assessing the 
heavy metal retention capacity. The samples collected are tested for its properties. The physical parameters, Atterberg limits, cation exchange capacity, $\mathrm{P}^{\mathrm{H}}$, grain size analysis are carried out and are included in Table 1 . These factors are essential to know the retention capacity of heavy metals part from temperature and reaction time. The atomic absorption principle is used to detect the concentration of heavy metal. It is reported from the study that the marine clay effectively retains heavy metals like lead, zinc, cadmium and copper in the decreasing order of proportion of heavy metals retained (Solly et al., 2014).

Studies on characteristics and strength improvement methods of Marine Clay

Many land reclamation carried out in many parts of the world and occurrences of soft clay particularly along the coast needed a detailed study of the characteristics of soil and strength behaviour. The addition of materials like

Table 1. Properties of marine clay.

\begin{tabular}{|c|c|c|c|c|c|c|c|c|c|c|c|c|c|c|c|}
\hline REFERENCE & $\begin{array}{l}\text { Depth of } \\
\text { sampling } \\
\text { (M) }\end{array}$ & $\begin{array}{l}\mathrm{W}_{1} \\
(\%)\end{array}$ & $\begin{array}{l}\text { Wp } \\
(\%)\end{array}$ & $\begin{array}{l}\text { Ip } \\
(\%)\end{array}$ & $\begin{array}{l}\text { Ws } \\
(\%)\end{array}$ & G & DFS & MDD & $\begin{array}{c}\mathrm{C} \\
\mathrm{t} / \mathrm{m}\end{array}$ & $\begin{array}{l}\text { salinity } \\
\mathrm{gm} / \mathrm{l}\end{array}$ & $\begin{array}{c}\text { NMC } \\
(\%)\end{array}$ & $\begin{array}{l}\text { ORMC } \\
(\%)\end{array}$ & $\mathrm{pH}$ & $\mathrm{CeC}$ & $\begin{array}{l}\mathrm{CC} \\
(\%)\end{array}$ \\
\hline $\begin{array}{c}\text { Koteswararao } \\
\text { et al., } 2011\end{array}$ & $0.4-1.0 \mathrm{~m}$ & 74.5 & 26.9 & 47.6 & 10.678 & 2.35 & 80 & $1.27 \mathrm{gm} / \mathrm{cc}$ & 12.2 & - & 86.15 & - & - & - & - \\
\hline $\begin{array}{l}\text { Solly } \\
\text { et al., } 2014\end{array}$ & - & 126 & 43.5 & 82.5 & 17.8 & 2.67 & 5.4 & & & & & & 7.56 & 31.4 & \\
\hline $\begin{array}{l}\text { Suksunhorpibulsuk } \\
\text { et al., } 2005\end{array}$ & 2 & 120 & 57 & - & - & 2.61 & & & & & 130 & & 8.8 & & \\
\hline $\begin{array}{l}\text { S.Bassack } \\
\text { et al., } 2009\end{array}$ & 10-Dec & 89 & 47 & 42 & 16 & 2.62 & - & $14.3 \mathrm{kn} / \mathrm{cum}$ & - & - & - & 7 & 7.2 & 30.8 & 23 \\
\hline \multirow[t]{4}{*}{$\begin{array}{c}\text { Jose } \\
\text { et al., } 1988\end{array}$} & 9.4 & 116.5 & 45.5 & 71 & 22.5 & 2.66 & - & - & - & 7.3 & 92 & 6.3 & 7.72 & - & - \\
\hline & 1 & 137.5 & 47.5 & 90 & 17.8 & 2.64 & - & - & - & 6.1 & 124 & 7.64 & 7.83 & 26 & 14 \\
\hline & 5.5 & 118.5 & 45.3 & 73.2 & 19.3 & 2.66 & - & - & - & 5.9 & 87 & 7.61 & 7.6 & 38.4 & 23.5 \\
\hline & 11.5 & 108 & 42.8 & 65.2 & 20.3 & 2.62 & - & - & - & 6.4 & 98 & 9.8 & 8.23 & 27 & 13.95 \\
\hline $\begin{array}{c}\text { Koteswararao } \\
\text { et al., } 2012\end{array}$ & 1.5 & 74.5 & 26.9 & 47.6 & 10.678 & 2.35 & 70 & $1.27 \mathrm{~g} / \mathrm{cc}$ & 12.2 & - & - & - & - & - & - \\
\hline $\begin{array}{l}\text { Sarada \& Venkata } \\
\text { Muthyalu, } 2015\end{array}$ & 0.3 & 74 & 27 & 47 & 12 & 2.38 & 70 & $1.27 \mathrm{~g} / \mathrm{cc}$ & 12.2 & - & - & - & - & - & - \\
\hline $\begin{array}{l}\text { Joseph } \\
\text { et al., } 2013\end{array}$ & - & 129 & 79 & - & 15 & - & - & - & - & - & - & - & - & - & - \\
\hline $\begin{array}{c}\text { Saranya \& } \\
\text { Muttharam } 2013\end{array}$ & $0.5-1.5$ & 86 & 29 & 57 & - & 2.43 & - & - & - & - & - & - & - & - & - \\
\hline $\begin{array}{c}\text { Bushra } \\
\text { \& Robinson } 2010\end{array}$ & 1.5 & 56 & 25 & - & - & 2.62 & - & - & - & - & - & 5.5 & 7.2 & & \\
\hline $\begin{array}{l}\text { Maheswari } \\
\text { et al., } 2013\end{array}$ & - & 52.9 & 27.5 & 25.4 & 23.5 & 2.44 & & 1.65 & - & - & - & - & - & - & - \\
\hline
\end{tabular}

Symbols used: $\mathrm{W}_{\mathrm{l}}$ : Liquid limit, $\mathrm{W}_{\mathrm{p}}$ : Plastic limit, Ip: Plasticity Index, $\mathrm{W}_{\mathrm{s}}$ : Shrinkage limit; DFS: Differential Free Swell, OMC: Optimum Moisture Content; MDD: Maximum Dry Density; C: Cohesion; ORMC: Organic Matter Content; CeC: Cation Exchange Capacity; CC: Calcium Carbonate. 
cement and clay has been generally adopted for improvement of characteristics of marine clay. Several admixtures are being tested for optimising the quantity of admixture. Both in situ studies and laboratory studies are carried out in many places to meet site specific requirements of strength, shear capacity, yielding of admixed marine clay.

The studies conducted all over the world address both investigation and assessment of behaviour of marine clay. The basic premise for strength improvement strategies are based first on the characteristics of marine clay and the target strength.

The influence of depositional and post depositional environment of clay was used by analysing the results of 203 pair of tests conducted on clay samples in 14 countries to assess the anisotropic strength ratio vs. plasticity index taking into consideration the depositional environments (won, 2013). Site specific variation in the properties and the purpose for which investigation and analysis lead to the choice of strength improvement methods.

Extensive characterization of marine clay has been carried out to assess the most influential parameter in consolidation of marine clay during the investigation of soil for the construction works involved in the Singapore for airport expansion. The clay formation is distinct in their characteristics between lower marine clay and upper marine clay formations in Singapore. Laboratory test were carried out to determine the physical properties and consolidation behaviour. Vertical hydraulic conductivity was determined by odometer consolidation tests. Horizontal hydraulic conductivity was established by carrying out Rowe cell tests. In situ test using piezocone, dilatometer, self boring pressure meter were reported to have been used for assessing the horizontal hydraulic conductivity. The influence of horizontal hydraulic conductivity and vertical hydraulic conductivity has been reported on consolidation with time (Arulrajah \& Bo 2008).

The marine clay in ulupandhan, Singapore was tested for the possible use of marine clay as a substitute for cement by investigating the pozzolanic reactivity. Finely ground quartz was used as filler material for the purpose of comparing with calcined clay (Du, \& Pang 2018).

In situ deep mixing is one of the technique for increasing the bearing capacity and reducing the settlement. An attempt has been made by conducting experimental investigation of soil of samples collected at a depth of $2 \mathrm{~m}$ below the ground taken from fukodomi town, saga Japan to derive a clay-water/cement ratio for admixed soft clay to fix the cement admixture quantity for achieving target strength in deep mixing. The study conducted involves determination of basic parameters such as Atterberg limits, specific gravity, $\mathrm{pH}$ value of pore fluid and concentration of sodium chloride. These are presented in Table 1. Clay -water/cement ratio of 7.5, 10 and 15 was obtained by through mixing to ensure uniform dispersion of admixing agent. Unconfined compression tests, consolidated drained, and consolidated un drained triaxial compression tests were out to determine the consolidation characteristics. It is reported that so long as the 
clay-water/cement ratio identity for cement admixed clays is maintained the strength and deformation characteristics would be identical (Horpibuluk et al., 2005).

The estimation of tensile strength of soils is required to assess the stability of slopes, earth filled dams, embankments and airfields. White clay, bentonite, marine clay have been taken up for the determination of properties of soils such as Atterberg limits, specific gravity and cation ion exchange capacity and an attempt has been made to establish an empirical formula for tensile strength by correlating the water content and the properties of soils. In the experimental investigation white clay, bentonite, marine clay and three locally available soil in Mumbai, India, is reported to have been used and physical parameters such as specific gravity, particle size distribution, Atterberg limits and plasticity index were obtained. The penetration resistance on the soil samples was studied with percentage of moisture content at 10, 20,30, 40, 50, 60 and 70 for prediction of tensile strength (Ravi Tej \& Singh 2013).

The basic parameters of Leda clay particularly Atterberg limits, plasticity index, and clay fraction, optimum water content and optimum dry density are studied in addition to salinity for assessing the shear behaviour of marine clay with concrete interface. In their experimental study, undisturbed samples were collected from Ottawa from depth that ranged between $8-12 \mathrm{~m}$ was used. The physical parameters, Atterberg limits, clay fraction, natural void ratio, sodium ion concentration, were determined. The liquid limit and plasticity index for salt contents at $4 \%, 10 \%$ and $20 \%$ were determined. It has been reported that the shear resistance increase with increase in dry density and salinity of Leda clay. The increase in the roughness of interface of concrete surface also reported to increased shear resistance (Taha \& Fall 2013).

The impact of vacuum preloading on the consolidation behaviour of Cochin marine clay was studied and it was reported that there is a substantial increase of $60 \%$ in the coefficient of consolidation with vacuum preloading while the time for $90 \%$ consolidation is reduced by $70 \%$ (Kirshnapriya et al., 2016).

Strength development of soft clay taken from a depth of $4 \mathrm{~m}$ in the Port Melbourne region, was studied by using fly ash and granulated blast furnace slag with varying proportion of admixtures. The unconfined shear strength was reported to increase significantly when the clay geo polymer proportion is increased to 20 and beyond up to $30 \%$ and is attributed to increase in the silicon and calcium in the medium (Yaghoubi et al., 2019).

The behaviour of admixed marine clay needs to be evaluated for its reliability and performance. The behaviour of fly ash cemented marine clay was often carried out under unconfined conditions while in reality the confinement pressure will exist. Sample collected from Singapore's south beach was tested using fly ash cement admixtures subjecting it to consolidated drained triaxial tests. It was reported that irrespective of the confining pressure the pore water pressure was stable when the axial strain was more than $10 \%$ (Cheng et al., 2018).

Cement admixed clay is often used for improving the strength. while the me- 
chanical behaviour were closely studied, the mineralogical correlation and the observed behaviour is studied in detail by using four different clays EPK kaolin, Speswhite kaolin, Nanticoke clay and Ottawa clay. The prepared clay was pulverised and mixed in to paste. Cement is mixed and samples were prepared having different moisture content, and cement content. These are then used for performing laboratory vane shear test. Several test results available on literature were also used for correlation. Two important findings reported are increase in strength beyond a curing time of three years and gain in strength being a function of activity number of soil as well as water content to cement content ratio (Sasanian \& Newson 2014).

The Marine clays are found in the states of West Bengal, Orissa, Andrapradesh, Tamilnadu, Kerala, Karnataka, Maharashtra and some parts of Gujarat India (Koteswararao et al., 2012). The parameters analysed from the marine clay samples at different locations predominantly along the Indian coast are primarily for adopting a most suited method for specific purposes and are confined to a specific location such as port development. The various parameters studied are brought out in Table 1 . The study of soil characteristics is carried out primarily for determining the strength and consolidation parameters. Marine clay deposits studied for the determination of the geotechnical properties used the soil collected from Kakinada India by Kakinada sea ports limited at depth varying from $0.4 \mathrm{~m}$ to $1.0 \mathrm{~m}$ is used for determining the geotechnical properties and the strength improvement using a combination of soil and fly ash at different proportion to determine the optimum level (Koteswararao et al., 2011). The study was carried out by adopting a combination of soil and fly ash at a proportion of $85: 15,82: 18,80: 20,78: 18$, and 75:25. Significant improvement in dry density was reported up to $20 \%$ addition of fly ash and it declined with further increase in the proportion of fly ash. The effect of addition of lime keeping the proportion of fly ash at $20 \%$ was tested varying the lime content from $5 \%$ to $7 \%$ keeping the incremental increase at $0.5 \%$. It was reported that soaked CBR and MDD values increased up to $6.5 \%$ lime addition, and it showed reduced beyond this percentage. The physical, chemical and mineralogical properties of marine clay collected from Visakhapatnam, India was used for establishing the strength and stiffness of soil-water matrix properties besides the properties under cyclic stress reversal (S bassack et al., 2009). The samples collected are from depth varying from $10-12 \mathrm{~m}$ about $10 \mathrm{~m}$ off the shoreline is reported to have been used. The samples had $14 \%$ sand, $27 \%$ silt and $59 \%$ clay by weight and exhibited a specific gravity of 2.62. The remoulded sample tested with varying moisture content indicated an optimum moisture content of $32 \%$ with a maximum dry density of $14.3 \%$.The chemical and physical properties of marine clay are tabulated in Table 1 .

The cement stabilisation is one of the most widely used methods for improving the strength of soft clays. Normally the behaviour is investigated in the laboratory study with a curing time of 7 days. The experimental investigation of Singapore upper marine clay and ordinary portland cement were used to pre- 
pare specimen. The specimens were cured up to 90 days and some were considered for curing time up to six months. Tri axial test were conducted on the samples. It is reported that the effect of curing time will diminish with consolidation stress higher than isotropic compression primary yield stress. However the damping effect would depend on the cement content (Xiao \& Lee 2008).

The X-Ray diffraction test was adopted for determining the mineralogical combination (Basack \& Purkayastha 2009; Jose et al., 1988). Study of physical and engineering properties of marine clay at Cochin, indicate that marine occur at different depths in greater cochin area drastically depending on the location. The samples collected in four locations around cochin are met with at different depth varying from $1-2 \mathrm{~m}$ to about $15 \mathrm{~m}$. The presence of decayed wood and charcoal at different depths is attributed to the fact that the cochin coastal belt is located in the uplifted area due to volcanic action (Jose et al., 1988).

Undisturbed samples are collected at depths of about $1 \mathrm{~m}$ from the depth of occurrence at any location. The natural moisture content is very high and is close to liquid limit and range from $76 \%$ to $128 \%$. X-ray diffraction analysis on soil samples indicated presence of felspar, mica, quartz, calcite and hematite. marine clay sample collected from Kakinada sea port limited from a depth of 0.3 $\mathrm{m}$ is used for characterising the properties of marine clay and strength improvement parameters by using different mixes of samples like marine clay, marine clay and fly ash, marine clay, fly ash and lime. The relationship between moisture content and dry density was studied in laboratory for various percentage of fly ash mixed with marine clay from $15 \%$ to $30 \%$ with an increment of $5 \%$.similar study was made by mixing lime at $4 \%, 5 \%, 7 \%, 8 \%, 9 \%$ and $10 \%$. These are use to find out consolidation behaviour study was reported to reveal that the coefficient of consolidation, consolidation index and rate of consolidation improved with addition of marine clay with fly ash, $\mathrm{cacl}_{2}$, lime and fly ash. The optimum levels of mixing the variation of coefficient of consolidation, consolidation index and rate of consolidation in days is enumerated (Sarada \& Venkata Muthyalu, 2015).

It has been reported that Marine clay found in coastal areas of Kerala exhibits high natural water content high levels of liquid limit and plastic limits with low compressibility and low shear strength. Study on the clays collected from Quilandy, Calicut was tested for its behaviour with lime stabilization (Joseph et al., 2013). The study was primarily focussed on using the dredged soft soil for filling purposes to the dredged soil additives such as lime was added to improve strength. The results of lime addition at different proportion from $0.2 \%$ to $0.8 \%$ with an incremental increase of 0.2 vs. the effect of geo textiles on the unconfined compressive strength (UCC) studies indicated substantial increase in UCC up to optimum level of around $0.4 \%$ and decrease thereafter. This percentage is remained almost constant and exhibited independent of the number of layer of geo textiles. However for the same lime content the addition geo textile increased the UCC substantially. The models studies were also done to integrate the geo textiles at different depths. The studies indicate that dredged soft marine 
clay can be used with the addition of lime and by placing geo textiles since considerable increase in the UCC is reported.

Study conducted on the natural soil collected from Velachery, Chennai, from a depth of 0.5 to $1.5 \mathrm{~m}$ from ground level was used to study the effect of consolidation stress on strength of lime stabilised soil It has been reported that The variation of UCC strength with variation in percentage of lime from $3 \%$ to $9 \%$, incremental increase being $2 \%$ and curing period 7, 14 and 28 days indicate an increase in UCC with increase in both the parameters (Saranya \& Muttharam 2013).

The behaviour of cement stabilised marine clay cured under stress was studied from samples collected from Ennore, Chennai was used for studying the curing stress both under drained and un drained conditions. The study was carried out at varying curing stress from 0 (atmospheric curing) 0,100 and $200 \mathrm{kpa}$ representing samples at depth $0 \mathrm{~m}, 5 \mathrm{~m}, 10 \mathrm{~m}$ and $20 \mathrm{~m}$ respectively. The influence of curing time of $1,3,7,14,28,60,90$ and 365 days were studied and reported with samples containing $10 \%, 15 \%$ and $20 \%$. The behaviour of lime stabilized marine clay showed an increase with the increase in the percentage of lime added. This increase is also seen when the curing time is increased (Robinson 2010).

Laboratory studies was made on the lime and saw dust treated marine clay for sub grade flexible pavement under cyclic pressure on samples collected from Kakinada port at depth of $0.5 \mathrm{~m}$ and the behaviour under various proportion of mixing of soil and sawdust (Koteswararao et al., 2012).

The effect of polyester fibres on strength properties of clayey soil of high plasticity using the soil collected from Bhal Chandra industry, dabhoi, Baroda was reported to increase the soaked CBR value with addition of polyester fibres (Kalpanamaheswari et al., 2013).

Marine clay and marine sand found in Indian offshore were taken to study the behaviour of marine sand-clay mixture under static and cyclic tri axial shear and the behaviour is reported (Prakasha \& Chandrasekaran 2005). From their detailed study, it was also conclusively established that the behaviour pattern could not be defined completely either with the void ratio of the granular void ration. A new parameter, effective void ratio was coined to define the behaviour of marine clay-sand mixtures by considering the ratio of volume of voids to volume of effective fraction.

An attempt has been made to develop an empirical equation based on the soil collected from Visakhapatnam marine clay sediments from various locations of industrial establishments to derive the compressibility of marine clays by studying the initial void ratio, shrinkage index, minus $425 \mu$ fraction and compression index (Satyanarayana 2010).

It has been reported that in western parts of India, large storage tanks are used for storing oil and are constructed on marine clay environment. These tanks are subjected to heavy wind and current load. Analysis have been carried out to study the settlement of pile group by taking into account tank empty condition 
and tank full condition. The concrete oil storage tanks of diameter $100 \mathrm{~m}$ and height $40 \mathrm{~m}$ supported by pile group is considered. The unit weight, moisture content and shear strength is considered as the analysis. It was reported that the Equivalent pier method when compared with interaction factor method gave more suitable analysis for ensuring safety of tank (Ravishankar \& Satyam 2015).

\section{Concluding Remarks}

The studies reported indicate that the untreated marine clay shows a decrease in the values of liquid limit and plasticity limit up to optimum value of admixture, beyond which these values decrease. It is further reported that the CBR value of untreated marine clay increases with increase in the percentage of mixing of fly ash at an optimum of $20 \%$. This value is reported to have increased by $87 \%$ with addition of lime at $6.5 \%$ optimum content.

With the increase in water content from $40 \%$ to $62 \%$, the unit cohesion sharply dropped from $30 \mathrm{kpa}$ to $10 \mathrm{kpa}$. The cyclic strain controlled tests on remoulded samples indicated a linear degradation index with number of cycles on $\log$-log scale.

When marine clay was mixed with additives such as fly ash and lime, the consolidation parameters such as coefficient of consolidation, increase with the addition of additives. The percentages of Additives depend on the basic characteristics of marine clay. When lime and use of two layers of geo textiles were used on dredged soft marine clay, the shear strength was enhanced substantially for effective use in land reclamation projects.

The marine clay when mixed with cement, light weight aggregate from industrial slag can be used to reclaim the land and can be adequately strengthened to take up heavy duty applications. The use of marine clay as an effective heavy metal absorbent is also feasible where ever required as a pollution control strategy.

Marine clay has been extensively studied for assessing its properties, behavior when admixed with materials like lime, cement, coir, husk, granite tile, industrial waste slag, shredded rubber and chemical additives. The suitability of marine clay for production of light weight aggregates, its heavy metal retention capacity and low permeability, increased strength with the addition of lime/cement makes it a valuable land fill material for land reclamation. Other materials impart desirable strength. However, long term effect on the behavior could be taken up for further studies and references.

\section{Conflicts of Interest}

The authors declare no conflicts of interest regarding the publication of this paper.

\section{References}

Anil Kumar, P. S., Sankar, N., \& Chandrakaran, S. (2010). Behaviour of Marine Clays under Cyclic Loading: A Study of Marine Clays of Kochi. International Journal of Earth 
Sciences and Engineering, 3, 85-90.

Arasan, S., Kagan Akbulut, F. R., Zaimoglu, A. S., \& Nasirpur, O. (2015). Rapid Stabilization of Sands with Deep Mixing Method Using Polyester. Periodica Polytechnica, Civil Engineering, 59, 405-411. https://doi.org/10.3311/PPci.7956

Arulrajah, A., \& Bo, M. W. (2008). Characteristics of Singapore Marine Clay at Changi. Geotechnical and Geological Engineering, 26, 431-441.

https://doi.org/10.1007/s10706-008-9179-2

Avinash, K., Kurian, P. J., Warrier, A. K., Shankar, R., \& Vineesh, T. C. (2015). Sedimentary Sources and Processes in the Eastern Arabian Sea: Insights from Environmental Magnetism, Geochemistry and Clay Mineralogy. Geoscience Frontiers, 7, 253-264. https://doi.org/10.1016/j.gsf.2015.05.001

Basack, S., \& Purkayastha, R. D. (2009). Engineering Properties of Marine Clays from the Eastern Coast of India. Journal of Engineering and Technology Research, 1, 109-114.

Bushra, I., \& Robinson, R. G. (2010). Strength Behaviour of Cement Stabilised Marine Clay Cured under Stress. In Indian Geotechnical Conference-2010 GEOtrendz (pp. 600-604). Mumbai Chapter \& IIT Bombay: IGS.

Cheng, Q. Q., Yao, K., \& Liu, Y. (2018). Stress-Dependent Behaviour of Marine Clay Admixed with Fly As-Blended Cement. International Journal of Pavement Research and Technology, 11, 611-616. https://doi.org/10.1016/j.ijprt.2018.01.004

Consoli, N. C., \& Prietto, P. (2006). Yielding-Compressibility-Strength Relationship for an Artificially Cemented Soil Cured under Stress. Geotechnique, 56, 69-72.

https://doi.org/10.1680/geot.2006.56.1.69

Du, H., \& Pang, S. D. (2018). Value-Added Utilization of Marine Clay as Cement Replacement for Sustainable Concrete Production. Journal of Cleaner Production, 198, 867-873. https://doi.org/10.1016/j.jclepro.2018.07.068

Elkateb, T. (2017). Stress-Dependent Consolidation Characteristics of Marine Clay in the Northern Gulf. Ains Shams Engineering Journal, 9, 2291-2299.

https://doi.org/10.1016/j.asej.2017.05.001

Gens, A., Valleja'N, B. A'nchez, M.S., Imbert, C., Villar, M.V., \& Vangeet, M. (2011). Hydromechanical Behaviour of a Heterogeneous Compacted Soil: Experimental Observations and Modelling. Geotechnique, 61, 367-386.

https://doi.org/10.1680/geot.SIP11.P.015

George, S., Paul, J., \& Jacob, J. (2014). Heavy Metal Retention of Cochin Marine Clay. International Journal of Engineering Research and Development, 9, 54-59.

Guo, L., \& Wu, D.-Q. (2018). Study of Leaching Scenarios for the Application of Incineration Bottom Ash and Marine Clay for Land Reclamation. Sustainable Environment Research, 28, 396-402. https://doi.org/10.1016/j.serj.2018.06.004

Horpibulsuk, S., Suddeepong, A., Chinkulkijniwat, A., \& Lu, M. D. (2012) Strength and Compressibility of Lightweight Cemented Clays. Applied Clay Science, 6911-6921. https://doi.org/10.1016/j.clay.2012.08.006

Horpibuluk, S., \& Suddeepong, R. R. A. (2011). Assessment of Strength Development in Blended Cement Admixed Bangkok Clay. Construction and Building Materials, 25, 1521-1531. https://doi.org/10.1016/j.conbuildmat.2010.08.006

Horpibuluk, S., Miur, N., \& Nagraj, T. S. (2005). Clay-Water/Cement Ratio Identity for Cement Admixed Soft Clays. Journal of Geotechnical and Geo Environmental Engineering, 131, 187-192. https://doi.org/10.1061/(ASCE)1090-0241(2005)131:2(187)

Indrarathna, B., Balasubramaniam, A. S., Poulos, H., Rujikiatkamjorn, C., \& Ameratunga, J. (2013). Performance and Prediction of Marine Clay Treated with Vacuum and Sur- 
charge Consolidation at Port of Brisbane. Australian Geomechanics Journal, 1484, 161-180.

Jose, B. T., Sridharan, A., \& Abraham, B. M. (1988). A Study of Geotechnical Properties of Cochin Marine Clays. Marine Geology, 7, 189-1988.

Joseph, A., Chandrakaran, S., Sankar, N., \& Jose, B. T. (2013). Studies on Behaviour of Lime Stabilized Marine Clay on Pre Compression. In Proceedings of Indian Geotechnical Conference (1-4).

Kirshnapriya, P. B., Sandeep, M. N., \& Antony, J. (2016). Efficiency of Vacuum Preloading on Consolidation Behaviour of Cochin Marine Clay. International Conference on Emerging Trends in Engineering, Science and Technology, 24, 256-262.

Koteswararao, D. Pranav, P. R. T., \& Ganja, V. (2012). A Laboratory Study on Lime and Sawdust Treated Marine Clay Sub Grade Flexible Pavement under Cyclic Pressure. International Journal of Engineering and Innovative Technology, 2, 207-210.

Koteswararao, D., Anusha, M., Pranav, P. R. T., \& Venkatesh, G. (2012). A Laboratory Study on the Stabilization of Marine Clay Using Saw Dust and Lime. International Journal of Engineering Science and Advanced Technology, 2, 851-862.

Koteswararao, D., Sruthi, M., \& Suryaditya, R. (2011). A Study on the Influence of Lime on Fly Ash Treated Marine Clay. International Journal of Engineering Science and Technology, 3, 6412-6422.

Leng, J., Liao, C., Ye, G., \& Jeng, D. S. (2018). Laboratory Study for Soil Structure Effect on Marine Clay Response Subjected to Cyclic Loads. Ocean Engineering, 147, 45-50. https://doi.org/10.1016/j.oceaneng.2017.10.020

Maheswari, K., Hsolanki, C., Atul, D., \& Desai, K. (2013). Effect of Polyester Fibers on Strength Properties of Clayey Soil of High Plasticity. International Journal of Scientific \& Engineering Research, 4, 486-491.

Mersi, G., \& Khan, A. Q. (2012). Ground Improvement Using Vacuum Loading Together with Vertical Drains. Journal of Geotechnical and Geoenvironmental Engineering, 138, 680-689. https://doi.org/10.1061/(ASCE)GT.1943-5606.0000640

Phetchuay, C., Horpibulsuk, S., Arulrajah, A., Suksiripattanapong, C., \& Udomchai, A. (2016). Strength Development in Soft Marine Clay Stabilized by Fly Ash and Calcium Carbide Residue Based Geopolymer. Applied Clay Science, 127-128, 134-142. https://doi.org/10.1016/j.clay.2016.04.005

Prakasha, K. S., \& Chandrasekaran, V. S. (2005). Behaviuor of Marine Sand-Clay Mixtures under Static and Cyclic Triaxial Shear. Journal of Geotechnical and Geoenvironmental Engineering, 131, 213-222. https://doi.org/10.1061/(ASCE)1090-0241(2005)131:2(213)

Rahman, Z. A., Yaacob, W. Z. W., Rahim, S. A., Lihan, T., \& Idris, W. M. R. (2013). Geotechnical Characterisation of Marine Clay as Potential Liner Material. Sains Malaysia, 42, 1081-1089.

Ravi Tej, P., \& Singh, D. N. (2013). Estimation of Tensile Strength of Soils from Penetration Resistance. International Journal of Geomechanics, 13, 496-501. https://doi.org/10.1061/(ASCE)GM.1943-5622.0000234

Ravishankar, P., \& Satyam, N. (2015). Interaction Analysis for Oil Storage Tanks on Marine Clay. International Journal of Geomate, 8, 1123-1129.

Sarada, T., \& Venkata Muthyalu, P. (2015). A Laboratory Study on Consolidation Characteristic of Marine Clay Treated with Fly Ash and Additives. International Journal on Recent \& Innovative Trend in Technology, 1, 42-54.

Saranya, K., \& Muttharam, M. (2013). Consolidation Stress Effect on Strength of Lime 
Stabilized Soil. International Journal of Engineering and Research Applications, 3, 1515-1519.

Sasanian, S., \& Newson, T. A. (2014). Basic Parameters Governing the Behaviour of Cement-Treated Clays. Soils and Foundation, 54, 209-224.

https://doi.org/10.1016/j.sandf.2014.02.011

Satyanarayana, B. R., \& Satyanarayana, C. N. V. (2010). Development of Empirical Equation for Compressibility of Marine Clays. In Indian Geotechnical Conference (pp. 886-887).

Shen, S.-L., Han, J., \& Du, Y.-J. (2008). Deep-Mixing Induced Property Changes in Surrounding Sensitive Marine Clays. Journal of Geotechnical and Geoenvironmental Engineering, 134, 845-854. https://doi.org/10.1061/(ASCE)1090-0241(2008)134:6(845)

Show, K.-Y., Lee, D.-J., Tay, J.-H., Hong, S.-Y., \& Chien, C.-Y. (2005). Lightweight Aggregates from Industrial Sludge-Marine Clay Mixes. Journal of Environmental Engineering, 131, 1106-1113. https://doi.org/10.1061/(ASCE)0733-9372(2005)131:7(1106)

Taha, A., \& Fall, M. (2013). Shear Behaviour of Sensitive Marine Clay-Concrete Interfaces. Journal of Geotechnical and Geoenvironmental Engineering, 139, 644-650. https://doi.org/10.1061/(ASCE)GT.1943-5606.0000795

Tsuchida, T., \& Tang, Y. X. (2015). Estimation of Compressive Strength of Cement-Treated Marine Clays with Different Initial Water Contents. Soils and Foundations, 55, 359-374. https://doi.org/10.1016/j.sandf.2015.02.011

Won, J. Y. (2013). Anisotropic Strength Ratio and Plasticity Index of Natural Clays. In Proceedings of the 18th International Conference on Soil Mechanics and Geotechnical Engineering (pp. 445-448).

Wu, D. Q., Xu, W. Y., \& Tjuar, R. (2015). Improvements of Marine Clay Slurries Using Chemical-Physical Combined Method (CPCM). Journal of Rock Mechanics and Geotechnical Engineering, 7, 220-225. https://doi.org/10.1016/j.jrmge.2015.02.001

Xiao, H. W., \& Lee, F. H. (2008). Curing Time Effect on Behaviour of Cement Treated Marine Clay. International Journal of Civil, Environmental, Structural Construction and Architectural Engineering, 2, 144-151.

Xiao, H. W., Lee, F. H., \& Chin, K. G. (2014). Yielding of Cement-Treated Marine Clay. Soils and Foundations, 54, 488-501. https://doi.org/10.1016/j.sandf.2014.04.021

Xiao, H., Wang, W., \& Goh, S. H. (2017). Effectiveness Study for Fly Ash Cement Improved Marine Clay. Construction and Building Materials, 157, 1053-1064. https://doi.org/10.1016/j.conbuildmat.2017.09.070

Yaghoubi, M. J., Arulrajah, A., Disfani, M. M., Horpibulsuk, S., Darmawan, S., \& Wang, J. (2019). Impact of Field Conditions on the Strength Development of a Geopolymer Stabilized Marine Clay. Applied Clay Science, 167, 33-42. https://doi.org/10.1016/j.clay.2018.10.005

Zainuddin, N., Yunus, N. Z. M., Al-Bared, M. A. M., Marto, A., Harahap, I. S. H., \& Rashid, A. S. A. (2019). Measuring the Engineering Properties of Marine Clay Treated with Disposed Granite Waste. Measurement, 131, 50-60. https://doi.org/10.1016/j.measurement.2018.08.053 